\title{
ACTITUD DE CAFETICULTORES SOBRE EL MANEJO Y CONSERVACIÓN DE SUELOS DEL SITIO RAMSAR, CASCADAS DE TEXOLO
}

\author{
ATTITUDES OF COFFEE PRODUCERS REGARDING SOIL MANAGEMENT AND \\ CONSERVATION IN THE CASCADAS DE TEXOLO, RAMSAR SITE
}

\author{
Juan C. Moreno-Seceña*, Martha E. Nava-Tablada, María I. Hernández-Sánchez \\ El Colegio de Veracruz. Carrillo Puerto No. 26 - Zona Centro - Xalapa, Veracruz, México. \\ 91000. (jmoreno_sece@hotmail.com).
}

\section{RESUMEN}

El cultivo del café (Coffea arabica L.) es de gran importancia económica, cultural y ambiental en el Sitio Ramsar Cascadas de Texolo y en su entorno, decretado como Área Natural Protegida. La degradación física, química y biológica del suelo en esta zona se ha incrementado; por lo que es prioritario realizar investigación tendiente a su manejo y conservación. El objetivo de este estudio fue conocer el historial y la actitud de cafeticultores del Sitio Ramsar Cascadas de Texolo hacia la adopción de prácticas de manejo y conservación del suelo. El estudio se realizó en localidades de Xico y Teocelo, Veracruz, mediante una encuesta que empleó un cuestionario aplicado a 40 cafeticultores cuya parcela se ubica dentro del polígono del Sitio Ramsar. Se encontró que las obras y prácticas de conservación de suelo fueron impulsadas al inicio de los ańos setenta por el desaparecido Instituto Mexicano del Café (INMECAFÉ) algunas de las cuales se siguen manteniendo y practicando. La edad promedio de los encuestados superó los 61 ańos, de los cuales $60 \%$ son pequeños propietarios, $22 \%$ medianos y $18 \%$ grandes. De los productores $80 \%$ alguna vez establecieron obras o ejecutaron prácticas de conservación. Sin embargo; actualmente sólo $45 \%$ sigue realizando prácticas de conservación de suelo dentro del Sitio, a pesar de haber sido denominado Ramsar. Se encontró una actitud ligeramente positiva (3.3), en escala de Likert, hacia la conservación del agroecosistema cafetalero. Productores con mayor superficie cultivada presentan mejor actitud hacia la conservación de suelo (4.4), lo que podría estar relacionado con que son los que tienen mayor grado de escolaridad. Se concluyó que las actividades tendientes a la conservación de suelo que se practican en el Sitio Ramsar fueron producto de capacitaciones anteriores que aún tienen influencia y que han ido reduciéndose considerablemente a pesar de existir

* Autor responsable * Author for correspondence.

Recibido: agosto, 2014. Aprobado: mayo, 2015.

Publicado como ARTÍCULO en ASyD 12: 553-566. 2015.

\section{Abstract}

Coffee (Coffea arabica L.) production is of great economic, cultural and environmental importance in the Cascadas de Texolo Ramsar Site and its surroundings, decreed as Natural Protected Area. The physical, chemical and biological degradation of the soil in this zone has increased, so it is a priority to carry out research that leads to its management and conservation. The objective of this study was to understand the history of coffee producers in the Cascadas de Texolo Ramsar Site and their attitude towards the adoption of practices for soil management and conservation. The study was performed in the localities of Xico and Teocelo, Veracruz, through a survey that used a questionnaire applied to 40 coffee producers whose plots were located inside the polygon of the Ramsar Site. It was found that the works and soil conservation practices were promoted at the beginning of the 1970s by the former Mexican Coffee Institute (Instituto Mexicano del Café, INMECAFÉ), some of which are still upheld and being practiced. The average age of those surveyed was over 61 years, of which $60 \%$ are small-scale landowners, $22 \%$ medium-scale and $18 \%$ large-scale. Of the producers, $80 \%$ had established works or executed conservation practices at some point. However, currently, only $45 \%$ continues to perform soil conservation practices inside the Site, despite it being denominated Ramsar. A slightly positive attitude (3.3), on the Likert scale, was found towards conservation of the coffee-producing agroecosystem. Producers with larger surface cultivated have a better attitude towards soil conservation (4.4), which could be related to the fact that they are the ones who have a higher degree of schooling. It was concluded that the activities that lead to soil conservation practiced in the Ramsar Site were product of prior trainings that still have influence and which have been decreasing considerably even if there is a positive attitude among coffee producers towards the resource's management and conservation.

Key words: agroecosystem, Coffea arabica L., disposition, conservation works. 
una actitud positiva entre los cafetaleros hacia el manejo y conservación del recurso.

Palabras clave: agroecosistema, Coffea arabica L., , disposición, obras de conservación.

\section{INTRODUCCIÓN}

$\mathrm{L}$ a producción de café (Coffea arabica L.) en México es una actividad de importancia ambiental, dado que es un cultivo cuyos impactos al agroecosistema no son tan severos como los de otros sistemas de producción (Pérez, 2009). Actualmente $40 \%$ de la producción se realiza en áreas con selvas altas y medianas, $23 \%$ en bosques de pinoencino, $21 \%$ en selvas bajas caducifolias y $15 \%$ en bosques mesófilos de montaña (AMECAFÉ, 2012); sin embargo; estas áreas han experimentado, debido a la crisis cafetalera, una reducida atención de las labores del cultivo e incluso un cambio de uso de suelo, alterando con esto el ciclo del $\mathrm{CO}_{2}$, del agua. Existe aumento de contaminantes, degradación del suelo y disminución de la biodiversidad (Foley et al., 2005). De esta forma, el uso del suelo presenta un dilema y un reto tendiente a desarrollar esquemas de manejo sustentable. Una de las prácticas que se han visto reducidas son las de manejo y conservación del suelo, entendiéndose ésta como el conjunto de labores parcelarias tendientes a prevenir, reducir o remediar su degradación. En 2012, la Organización de las Naciones Unidas para la Alimentación y la Agricultura (FAO) y la Reseńa Mundial de Enfoques y Tecnologías de la Conservación (WOCAT), definen a la conservación del suelo como el conjunto de actividades a nivel local que mantienen o aumentan la capacidad productiva de la tierra en áreas afectadas por (o propensas a) la degradación. Dicha conservación incluye obras de prevención o de reducción de la erosión, control de salinidad; conservación del drenaje; y mantenimiento o mejoramiento de su fertilidad.

En la zona de Xico y Teocelo, el café tiene gran importancia económica, cultural y ambiental (NavaTablada, 2012). Las áreas de cultivo en esta región se extendieron con gran rapidez durante el inicio de la década de 1940 (Hoffmann, 1986; Biarnes y Duchenne, 1987) invadiendo espacios naturales del bosque mesófilo de montaña característico del lugar, por lo que hoy día predomina el agroecosistema con café bajo sombra. En el año 2006, un polígono territorial

\section{INTRODUCTION}

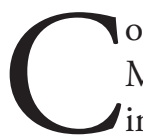
offee (Coffea arabica L.) production in México is an activity of environmental importance, since it is a crop whose impacts on the agroecosystem are not as severe as those of other production systems (Pérez, 2009). Currently, $40 \%$ of the production is carried out in areas with high and medium forests, $23 \%$ in pine-oak forests, $21 \%$ in low deciduous forests, and $15 \%$ in mountainous mesophyll forests (AMECAFÉ, 2012); however, these areas have experimented, due to the coffee crisis, reduced attention to the cultivation tasks and even a change in land use, altering with this the $\mathrm{CO}_{2}$ cycle, and the water cycle. There is an increase in contaminants, soil degradation and a reduction in biodiversity (Foley et al., 2005). Thus, soil use presents a dilemma and a challenge leading to develop schemes for sustainable management. One of the practices that have been reduced are those of soil management and conservation, understanding it as the set of plot tasks that lead to preventing, reducing or remediating its degradation. In 2012, the Food and Agriculture Organization of the United Nations (FAO) and the World Overview of Conservation Approaches and Technologies (WOCAT) defined soil conservation as the set of activities at the local level that maintain or increase the productive capacity of land in areas affected by (or prone to) degradation. Such conservation includes works for prevention or reduction of erosion, salinity control, drainage conservation, and maintenance or improvement of fertility.

In the Xico and Teocelo zone, coffee has great economic, cultural and environmental importance (Nava-Tablada, 2012). The cultivation areas in this region extended very quickly during the beginning of the 1940s (Hoffmann, 1986; Biarnes and Duchenne, 1987), invading natural spaces of the mountainous mesophyll forest characteristic of the region, so that the shade coffee agroecosystem predominates today. In the year 2006, a territorial polygon of 500 ha in the Xico and Teocelo zone, which includes the Cascadas de Texolo and lands surrounding them, was recognized as a Ramsar Site (Secretaría de la Convención Ramsar, 2007). Currently in this Site (Figure 1), there is no official resource management plan. Some owners do not know that their lands are 


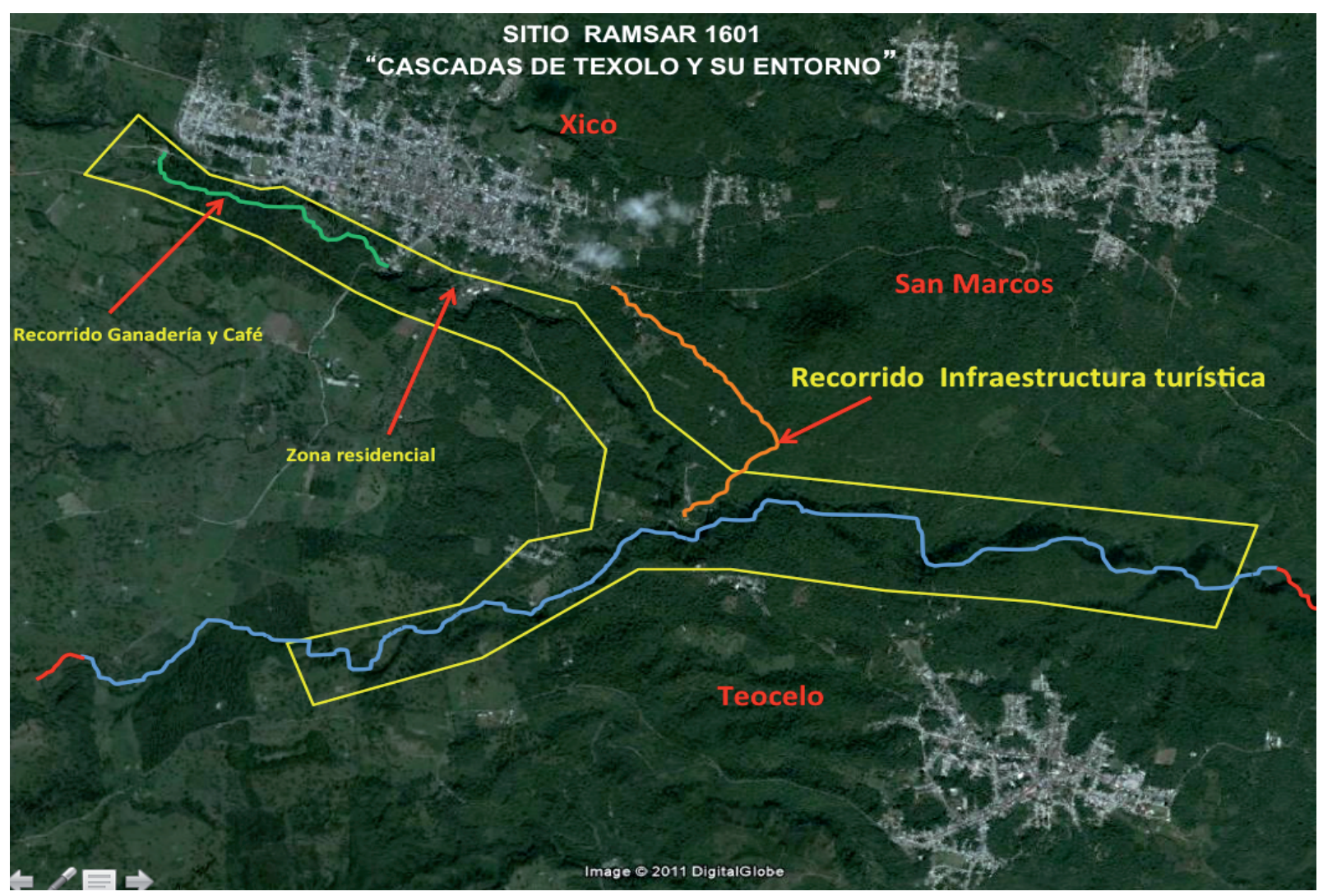

Figura 1. Ubicación geográfica del Sitio Ramsar, Cascadas de Texolo y su entorno.

Figura 1. Geographical location of the Ramsar Site, "Cascadas de Texolo and surroundings".

de 500 ha de la zona de Xico y Teocelo, que incluyen las Cascadas de Texolo y predios de su entorno fue reconocido como Sitio Ramsar (Secretaría de la Convención Ramsar, 2007). Actualmente en este Sitio (Figura 1), oficialmente no se cuenta con un plan de manejo de los recursos. Algunos propietarios desconocen que sus terrenos se encuentran en un Área Natural Protegida, además de que la zona residencial, la actividad ganadera y turística principalmente, van invadiendo el polígono (Rojo, 2011). Al respecto Flores en 2011, inició algunos trabajos tendientes a aplicar estrategias de sensibilización a habitantes y usufructuarios, para afrontar los problemas citados, sin lograr resultados alentadores, debido a que estas estrategias terminaron siendo un diagnóstico de la problemática donde sólo involucró la participación de turistas y habitantes que no necesariamente tienen propiedades en el sitio.

En relación con la producción de café en el Sitio, ésta ha experimentado diversas transformaciones a través de los años, pasando de una producción química a una producción que pudiera considerarse "orgánica" (aunque carente de certificación), ya que inside a Natural Protected Area, and in the residential zone, livestock and tourist activities, mainly, are invading the polygon (Rojo, 2011). In this regard, Flores began in 2011 some works aimed at applying strategies to increase awareness in residents and beneficial owners, to face the problems mentioned, without achieving encouraging results, because these strategies ended up being a diagnosis of the problematic where only the participation of tourist and residents who do not necessarily own properties in the site was involved.

Regarding coffee production in the Site, it has experienced various transformations throughout the years, going from chemical production to production that could be considered "organic" (although lacking certification), since because of the impact of the coffee production crisis, practices such as fertilization, chemical control of pests and diseases, have decreased considerably, something that is favorable to conserve the Site, but which has also caused for the producer to choose to sell his plot and for the Site to experience a change in land use, with those who continue to produce coffee being affected by the low productivity 
por el impacto de la crisis cafetalera se han disminuido considerablemente las prácticas de fertilización, control químico de plagas y enfermedades, lo cual ha sido favorable para conservar el Sitio, pero también ha causado que el productor opte por vender su predio y el Sitio experimente el cambio de uso de suelo, y los que continúan produciendo café, resienten la baja productividad y calidad del producto (Noriega Altamirano et al., 2014). Aunado a lo anterior, el uso inadecuado del recurso suelo y la falta de atención a su conservación y mantenimiento ha provocado su degradación física, química y biológica, provocando principalmente erosión y pérdida de fertilidad (Rojo, 2011; Hernández, 2014). Es por ello que el presente trabajo de investigación tuvo como objetivo general conocer el historial y la actitud de cafeticultores del Sitio Ramsar Cascadas de Texolo hacia la adopción de prácticas de manejo y conservación de suelo. Considerando la actitud como la posición adoptada por una persona ante una situación de naturaleza variada, que la hace reaccionar ante ésta generando una atracción, repulsión o indiferencia y que se traduce en la posterior aceptación o rechazo de la misma (Altamirano et al., 2004). Este tipo de estudios de actitud alcanzó relevancia después de los trabajos de Likert (1932); sin embargo, en el área agrícola y ambiental, son escasas las investigaciones que permiten conocer la actitud del agricultor frente a determinadas situaciones. Para el presente trabajo se planteó la hipótesis de que las prácticas de conservación y manejo de suelo que hoy imperan fueron producto de capacitaciones anteriores que aún tienen influencia y que han ido reduciéndose considerablemente, a pesar de existir una actitud positiva entre los cafetaleros hacia el manejo y conservación del recurso suelo.

\section{Materiales y Métodos}

\section{Área de estudio}

El presente estudio se realizó durante el primer semestre de 2014 en el Sitio Ramsar Cascadas de Texolo y su entorno, el cual se ubica entre los límites de los municipios de Xico y Teocelo, en la zona centro del estado de Veracruz, sobre las estribaciones Orientales del Cofre de Perote (Arriaga et al., 2002). Se localiza entre 1100 y 1400 m de altitud, los suelos presentes van desde andosoles (negros y con contenido de material volcánico), húmicos (profundos, muy and quality of the product (Noriega Altamirano et al., 2014). In addition to this, the inadequate use of the soil resource and the lack of attention for its conservation and maintenance have caused its physical, chemical and biological degradation, provoking primarily erosion and loss of fertility (Rojo, 2011; Hernández, 2014). This is why this research study had the general objective of understanding the history of coffee producers in the Cascadas de Texolo Ramsar Site and their attitude towards the adoption of soil management and conservation practices. Attitude is understood as the position adopted by a person when faced with a situation of varied nature, which makes him/her react to it by generating an attraction, repulsion or indifference, and which translates into the later acceptance of rejection of it (Altamirano et al., 2014). This type of studies about attitude reached relevance after Likert's studies (1932); however, in the agricultural and environmental area, studies that allow understanding the attitude of the farmer in face of specific situations are scarce. For this study, the hypothesis we suggested is that the soil conservation and management practices that prevail today were the product of previous trainings that still have influence and which have been decreasing considerably, despite there being a positive attitude among the coffee producers towards management and conservation of the soil resource.

\section{Materials and Methods}

\section{Study area}

This study was carried out during the first semester of 2014 at the Cascadas de Texolo Ramsar Site and its surroundings, which is located between the limits of the Xico and Teocelo municipalities, in the central zone of the state of Veracruz, on the eastern foothills of Cofre de Perote (Arriaga et al., 2002). It is located between 1100 and $1400 \mathrm{~m}$ of altitude, the soils present range from andosols (black and with volcanic material content), humic (deep, very porous, silty), ferrallitic (deep, clayey, slightly porous) and litosols (shallow soil, limited by rocky material) (Ruelas et al., 2012 cited by Hernández, 2014). In addition, there are deep ravines, with rocky outcrops (Torres, 2005) that contribute naturally to the hydric erosion of soil. Four localities from Xico and four from Teocelo were included. 
porosos, limosos), ferralíticos (profundos, arcillosos, poco porosos) y los litosoles (suelo poco profundo, limitado por material rocoso) (Ruelas et al., 2012 citado por Hernández, 2014). Además existen barrancas profundas, con afloramientos rocosos (Torres, 2005) que contribuyen de manera natural a la erosión hídrica del suelo. Se incluyeron cuatro localidades de Xico y cuatro de Teocelo.

La primera fase del proyecto consistió en el análisis del historial de prácticas de manejo del suelo en la región. Para ello, se identificaron trabajos en campo y análisis de información documental relacionada con el estudio. Además se usó la técnica del sondeo, mediante recorridos de campo y entrevistas con informantes clave (Folgueiras, 2007). En la segunda fase se realizó una encuesta aplicando un cuestionario mediante la técnica "bola de nieve" (Sandín, 2003), contó con un padrón georeferenciado de las parcelas con los nombres de los cafeticultores propietarios.

El cuestionario se aplicó a 40 productores del Sitio Ramsar; lo anterior representa $12.5 \%$ de productores con predios en el Sitio y $37 \%$ de su superficie, de acuerdo con el padrón cafetalero 2008. Para un análisis más puntual, se tomó como base tres estratos de productores, en relación con el número de hectáreas de su parcela, esto es: a) $\leq 5.0$; b) $5.1-10$; c) $>10$. El cuestionario estuvo integrado por 25 preguntas; 16 abiertas y nueve cerradas distribuidas en tres apartados: 1) datos generales del productor y la finca, 2) aspectos técnicos-productivos e históricos sobre conservación de suelo, y 3) aspectos de actitud del productor.

\section{Análisis de la actitud}

Para estimar la actitud se usó el índice de Likert considerando el promedio de las respuestas de nueve reactivos con cinco opciones: 5 indica "Totalmente de acuerdo"; 4 "De acuerdo"; 3 "Indiferente"; 2 "En desacuerdo"; 1 "Totalmente en desacuerdo". Para interpretarla (Cuadro 1) se consideró el criterio de Hartley (2014).

\section{Análisis estadísticos}

Los datos obtenidos se capturaron en el programa Microsoft Office Excel (versión 2010) obteniéndose estadísticas descriptivas, coeficientes de correlación y diagramas de frecuencia.
Cuadro 1. Interpretación escala de Likert.

Table 1. Interpretation Likert scale.

\begin{tabular}{ll}
\hline Indice de Likert & \multicolumn{1}{c}{ Interpretación } \\
\hline$<1.5$ & Negativa baja \\
$1.6-2.2$ & Ligeramente negativa \\
$2.3-3.0$ & Indiferente \\
$3.1-3.8$ & Ligeramente positiva \\
$>3.9$ & Altamente positiva \\
\hline
\end{tabular}

The first phase of the project consisted in the analysis of the history of soil management practices in the region. For this purpose, field tasks were identified and documentary information related to the study was analyzed. Also, the technique of surveying was used, through field visits and interviews with key informants (Folgueiras, 2007). In the second phase, a survey was performed by applying a questionnaire through the "snowball" technique (Sandín, 2003), had a georeferenced pattern of the plots with the names of land-owning coffee producers.

The questionnaire was applied to 40 producers from the Ramsar Site; this represents $12.5 \%$ of producers with plots in the Site and $37 \%$ of its surface, according to the coffee production census of 2008. For a more detailed analysis, three strata of producers were taken as a base, in relation to the number of hectares in their plot; that is: a) $\leq 5.0$; b) $5.1-10$; c) $>10$. The questionnaire was made up of 25 questions; 16 open ones and nine closed ones, distributed into three sections: 1) general data of the producer and the farm, 2) technical-productive and historical aspects about soil conservation, and 3) producer's attitude aspects.

\section{Analysis of the attitude}

To estimate the attitude, the Likert index was used, considering the average of the responses to nine reagents with five options: 5 indicates "Totally agree"; 4 "Agree"; 3 "Indifferent"; 2 "Disagree"; 1 "Totally disagree". To interpret it (Table 1 ), the Hartley criterion was considered (2014).

\section{Statistical analysis}

The data obtained were captured in the Microsoft Office Excel software (version 2010), obtaining descriptive statistics, correlation coefficients, and diagrams of frequency. 


\section{Resultados y Discusión}

\section{Historial del manejo y conservación del suelo en el Sitio}

La región de Xalapa-Coatepec-Xico fue una de las primeras áreas de México donde se introdujo el cultivo de café vía la zona de Córdoba a fínales del siglo XVIII (Ejea Mendoza, 2009). Los primeros trabajos de conservación del suelo en el Sitio se remontan a finales del siglo XIX cuando el cultivo se empieza a introducir. El desmonte provocado en el lugar para dar cabida a la plantación de café en terrenos accidentados, rocosos y áreas de barrancas con niveles de precipitación de 1200 a 1500 mm, generó la necesidad de llevar al cabo prácticas de conservación del suelo. Las primeras prácticas de conservación eran muy rudimentarias, consistían en: uso de cobertura vegetal viva, uso de fajas de contención, uso de barreras muertas (piedra, madera o montículos de suelo) e incorporación de residuos orgánicos. Durante el periodo de 1965 a 1985, las prácticas de conservación de suelo fueron más técnicas o especializadas, esto es, aplicadas conforme al tipo de suelo, incluso se llegaron a construir obras de conservación. Dichas obras y prácticas fueron promovidas mediante capacitación y financiamiento por el INMECAFÉ. Producto del trabajo de éste proyecto se detectaron obras como: uso de barreras vivas, implementación de terrazas individuales, terrazas de banco, muros de concreto, y ollas de captación.

En las entrevistas con productores, sus familias, con asesores de organizaciones y lugareños, se detectó que la mayoría de las transformaciones que la cafeticultura del Sitio experimentó se consolidaron entre los años setenta y mediados de los ochenta; transformaciones que se manifiestan concretamente en la vida regional, y algunas han seguido presentes en el modo de producción que actualmente impera. Estas prácticas fueron impulsadas por conocimientos técnico-productivos difundidos por el Instituto Mexicano del Café (INMECAFÉ), el cual tenía una visión productivista que promovía el uso de insumos: agroquímicos, fertilizantes, créditos, protección del suelo y paquetes tecnológicos modernos. Después de la caída del precio del café en 1989, esta imagen fue cambiando, deteriorándose el nivel de ingreso y la dinámica de movilización regional del cafeticultor

\section{Results AND Discussion}

\section{History of soil management and conservation in the Site}

The region of Xalapa-Coatepec-Xico was one of the first areas in México where coffee cultivation was introduced via the zone of Córdoba, at the end of the $18^{\text {th }}$ Century (Ejea Mendoza, 2009). The first soil conservation works in the Site date back to the end of the $19^{\text {th }}$ Century when the crop started to be introduced. The clearing that happened at the place to make way for the coffee plantations on rugged, rocky, landscapes and areas with ravines with precipitation levels of 1200 to $1500 \mathrm{~mm}$, generated the need to carry out practices for soil conservation. The first conservation practices were quite rudimentary, consisting in: use of live plant coverage, use of contention belts, use of dead barriers (stone, wood or mounds of dirt), and incorporation of organic residues. During the period between 1965 and 1985, the soil conservation practices were more technical or specialized, that is, applied according to the type of soil, and conservation works were even constructed. These works and practices were promoted through training and financing by INMECAFÉ. The following works were detected as product of the tasks done in this project: use of live barriers, implementation of individual terraces, bank terraces, concrete walls, and catchment pots.

In the interviews with producers, their families, organization advisors and residents, it was detected that most of the transformations that coffee production underwent at the Site were consolidated between the 1970s and the mid-1980s; these transformations are manifested concretely in regional life, and some have continued to be present in the production mode that prevails today. These practices were fostered by technical-productive knowledge divulged by the Mexican Coffee Institute (INMECAFÉ), which had a productivity vision that promoted the use of inputs: agrichemicals, fertilizers, credit, soil protection and modern technological packages. After the fall of the coffee price in 1989, this image started to change, with the level of income and the regional mobilization dynamics of coffee producers and their families deteriorating. The mobility dynamics of the workforce within the region was reduced and it gave 
y sus familias. La dinámica movilidad de mano de obra dentro de la región se redujo y dio lugar a la migración laboral hacia otros lugares del país y Estados Unidos. Lo anterior impactó además en las prácticas a nivel parcelario.

En cuanto a las prácticas de conservación de suelo, se dejaron de realizar por escasez de mano de obra familiar, por lo que a inicios del año 2000 se regresó a la producción con cero insumos en el cultivo del café, reduciéndose incluso las prácticas de fertilización y de conservación de suelo que demandaban inversión de recurso económico por el productor. Actualmente las prácticas de conservación de suelo que se siguen implementando son aquellas que no implican uso excesivo de mano de obra e inversión económica, por lo que se observan en la región prácticas usuales como: uso de barreras vivas (intercalado de cultivos frutales y forestales), aplicación de barreras muertas (muros de piedra, adición de hojarascas y materia orgánica al suelo).

\section{Perfil Del productor}

La edad media del productor encuestado fue 61.3 años $(s=13.9)$, con escolaridad promedio de 7.9 años $(s=6.4)$ (Cuadro 2). De los cafetaleros que respondieron la encuesta $75 \%$ son del género masculino y $25 \%$ femenino. Se observa que $60 \%$ de los cafetaleros encuestados poseen una superficie de producción menor a 5.0 ha. La mayor escolaridad corresponde a productores con mayor extensión de terreno.

\section{ASPECTOS TÉCNICOS, PRODUCTIVOS E HISTÓRICOS SOBRE CONSERVACIÓN DE SUELO}

El productor siembra en su finca una diversidad de variedades de café. El $20 \%$ tiene una sola, $20 \%$ dos, $40 \%$ tres y el resto más de tres. De los cafetaleros $62.5 \%$ tiene más de 30 años de experiencia en place labor migration towards other places in the country and the United States. This also impacted the practices at the land plot level.

With regard to the practices for soil conservation, they ceased to be carried out because of scarcity in family labor, so that at the beginning of the year 2000 there was a return to production with zero inputs in coffee production, and even the fertilization and soil conservation practices that demanded an investment of economic resources by the producer were reduced. Currently, the soil conservation practices that are still being implemented are those that do not entail the excessive use of labor and financial investment, so the usual practices observed in the region are: use of live barriers (interspersing fruit trees and forest crops), applying dead barriers (stone walls, adding dead leaves and organic matter to the soil).

\section{Profile of The PRODUCER}

The mean age of the producer surveyed was 61.3 years $(s=13.9)$, with average schooling of 7.9 years $(s=6.4)$ (Table 2$)$. Of the coffee producers who responded the survey, $75 \%$ are males and $25 \%$ females. It is observed that $60 \%$ of the coffee producers surveyed own a production surface smaller than 5.0 ha. The highest schooling corresponds to producers with a larger area of land.

\section{TeCHNICAL, PRODUCTIVE AND HISTORICAL ASPECTS ABOUT SOIL CONSERVATION}

The producers sow in their farms a diversity of coffee cultivars. There are $20 \%$ with only one cultivar, $20 \%$ with two, $40 \%$ with three, and the rest with more than three. Of coffee producers, $62.5 \%$ have more than 30 years of experience in coffee production. Regarding this, Salas (2002) points out that experience is something key for the adoption

Cuadro 2. Edad y escolaridad de los productores cafetaleros del Sitio Ramsar "Cascadas de Texolo y su entorno". Table 2. Age and schooling of coffee producers from the Ramsar Site "Cascadas de Texolo and surroundings".

\begin{tabular}{lcccrrrr}
\hline $\begin{array}{l}\text { Estrato } \\
\text { (No.) }\end{array}$ & $\begin{array}{c}\text { Superficie } \\
\text { (ha) }\end{array}$ & $\mathrm{n}$ & $\%$ & \multicolumn{3}{c}{ Edad (años) } & \multicolumn{3}{c}{ Escolaridad (ańos) } \\
\cline { 5 - 9 } & $\leq 5.0$ & 24 & 60 & 64.0 & $(14.9)^{\dagger}$ & 6.2 & $(5.7)^{\dagger}$ \\
2 & $5.1-10.0$ & 9 & 22.5 & 58.3 & $(9.2)$ & 6.5 & $(6.5)$ \\
3 & $\geq 10.0$ & 7 & 17.5 & 55.7 & $(14.6)$ & 15.6 & $(3.0)$ \\
\hline Total & & 40 & 100 & 61.3 & $(13.9)$ & 7.9 & $(6.4)$ \\
\hline
\end{tabular}

${ }^{\dagger}$ Desviación estándar entre paréntesis. • Standard deviation in parenthesis. 
la cafeticultura. Al respecto Salas (2002) señala que la experiencia es clave para la adopción y puesta en práctica de las innovaciones, y Pérez et al. (1997) sostienen que cuando el agricultor tiene más experiencia en la realización de sus labores es más propenso a la adopción de tecnologías. Los años que un agricultor tiene en sus labores diarias le permiten llegar a manejar con habilidad y destreza la mayoría de las condiciones del medio que lo rodean y tomar decisiones con conocimiento de causa. Sólo 22.5 \% de los productores encuestados fertiliza; de éstos, la dosis de fertilización media general anual aplicada, es de 54-85-08 $\mathrm{kg} \mathrm{ha}^{-1}$ (N, P y K). De los productores que aplican fertilizantes $80 \%$ utilizan fuentes inorgánicas, a base de urea (46-0-0), fosfato diamónico (DAP) (18-46-0), y mezclas como 20-10-10. En relación al historial de conservación de suelos, $80 \%$ realizó consecutivamente prácticas de conservación de suelos. Actualmente sólo $45 \%$ realiza éste tipo de prácticas. La anterior reducción obedece al nulo impulso de programas de manejo a nivel parcelario, la crisis cafetalera que disminuyó los ingresos para poderlos destinar a éste tipo de prácticas. Además se suma el desconocimiento de las acciones tradicionales de conservación por parte de las nuevas generaciones que se vienen insertando en el sistema productivo del café (Cotler et al., 2007).

Del $45 \%$ de entrevistados que realizan prácticas a favor del suelo, se enlistaron (Cuadro 3) se constataron mediante visitas a la finca algunas como: barreras muertas, barreras vivas, aplicación de hojarasca, terrazas, curvas de nivel y ollas de captación. Existen otras prácticas que, desde la percepción del productor, se consideran de conservación de suelo, tales como: chapeo con machete, despiedre, cero aplicación de agroquímicos, siembra de especies arbóreas. Se observó que existen aún obras de concreto que fueron construidas durante la década de los setenta.

Asímismo se observó notar que los productores con una superficie mayor a 10 ha son los que actualmente realizan más prácticas de conservación de suelos $(85.7 \%)$, mientras que en productores con superficie menor, es de $41.6 \%$. Además, los productores considerados como grandes son aquellos con menor edad y mayor escolaridad, que presentan mayor conocimiento sobre los beneficios que conlleva el atender al recurso suelo como elemento importante del agroecosistema. Respecto a la edad, BetancourtYánez y Pulido (2006) mencionan que una población and implementation of innovations, and Pérez et al. (1997) state that when the farmer has more experience in performing his tasks, he is more prone to adopting the technologies. The years that a farmer has been performing his daily tasks allow him to manage skillfully and with dexterity most of the conditions of the environment surrounding him, and to make decisions with first-hand knowledge. Only $22.5 \%$ of the producers surveyed fertilize the soil; of these, the general mean annual dose of fertilization applied is $54-85-08 \mathrm{~kg} \mathrm{ha}^{-1}(\mathrm{~N}, \mathrm{P}$ and $\mathrm{K})$. Of the producers who apply fertilizers, $80 \%$ use inorganic sources, urea-based (46-0-0), diammonium phosphate (1846-0), and mixtures such as 20-10-10. Regarding the history of soil conservation, $80 \%$ carried out soil conservation practices consecutively. Currently only $45 \%$ perform this type of practices. This reduction obeys to the null impulse of management programs at the plot level, the coffee crisis that decreased the income available to destine to this type of practices. In addition, the lack of understanding of traditional conservation actions by the new generations who are entering the coffee productive system is also added (Cotler et al., 2007).

Of the $45 \%$ of people interviewed who perform practices in favor of the soil, some were listed (Table 3) and confirmed through visits to the farm: dead barriers, live barriers, applying dead leaves, terraces, level curves and catchment pots. There are other practices which, from the perception of the producer, are considered soil conservation, such as: clearing with machete, removing rocks, zero application

Cuadro 3. Principales prácticas de conservación de suelos que se realizan en el Sitio.

Table 3. Principal soil conservation practices that are carried out in the Site.

\begin{tabular}{lcc}
\hline Práctica & Frecuencia & $\%$ \\
\hline Curvas de nivel & 7 & 17.5 \\
Incorporación de hojarasca & 9 & 22.5 \\
Barreras vivas & 7 & 17.5 \\
Barreras muertas & 6 & 15.0 \\
Terrazas & 6 & 15.0 \\
Despiedre & 2 & 5.0 \\
Ollas de captación & 3 & 7.5 \\
\hline Total & 40 & 100.0 \\
\hline
\end{tabular}

Frecuencia de respuesta: todos mencionaron más de una. Frequency of response: they all mentioned more than one. 


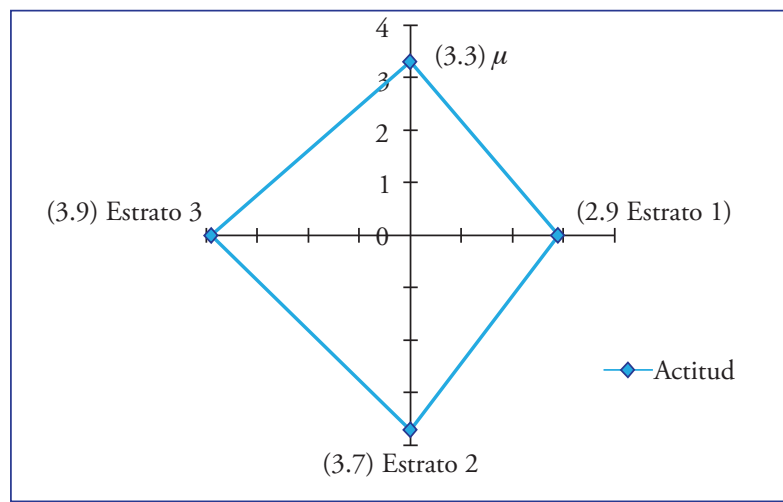

Figura 2. Actitud media en cada estrato, respecto a la conservación del agroecosistema cafetalero en el Sitio Ramsar.

Figura 2. Average attitude in each stratum, regarding conservation of the coffee production agroecosystem in the Ramsar Site.

con un alto porcentaje de agricultores jóvenes presenta un amplio potencial para mejorar el sistema productivo local debido a que se observa por lo general menor resistencia a los cambios de producción. Esta condición podría incidir positivamente en la adopción de tecnología y enseñanzas ambientales. Salas (2002) agrega que las actitudes se aprenden a través de la observación e imitación de personas mayores.

\section{AsPECTO ACTITUDINAL}

$\mathrm{Al}$ abordar el aspecto actitudinal, la primera afirmación que se presentó fue: estoy dispuesto a conservar el medio ambiente y sus recursos en beneficio del Sitio Ramsar donde se encuentra mi finca de café. $\mathrm{Al}$ respecto, se registró una media aritmética en la población de una actitud ligeramente positiva (3.3) en la escala de Likert, se observó que al hacer el análisis por estratos (Figura 2), los productores del estrato tres (grandes en superficie producida de café) fueron aquellos que presentaron la mayor actitud (3.9), seguido por los medianos (3.7) y finalmente por los pequeños (2.9). Lo anterior puede estar relacionado con que los productores de los estratos dos y tres presentan un grado de escolaridad superior.

Los ocho reactivos restantes para efectos de análisis, se presentan en el Cuadro 4. Todos se abordan en forma de afirmación positiva y se enlistan a continuación:

A. La conservación del suelo es necesaria para mi trabajo en la producción de café; of agrichemicals, planting tree species. It was observed that there are still concrete works that were constructed during the 1970s.

Likewise, it was noticed that the producers with a surface larger than 10 ha are the ones that currently perform more soil conservation practices $(85.7 \%)$, while among producers with smaller surfaces, it is $41.6 \%$. In addition, the producers considered as large-scale are those who with less age and more schooling, who present greater knowledge about the benefits that taking care of the soil resource as an important element of the agroecosystem entails. With regard to age, Betancourt-Yánez and Pulido (2006) mention that a population with a high percentage of young farmers presents broad potential to improve the local productive system because lower resistance to changes in production is generally observed. This condition could influence positively the adoption of technology and environmental teaching. Salas (2002) adds that attitudes are learned through observation and imitation of older people.

\section{Attitudinal aspect}

When addressing the attitudinal aspect, the first response present was: I'm willing to conserve the environment and its resources in benefit of the Ramsar Site, where my coffee plantation is located. In this regard, an arithmetic mean was seen in the population of a slightly positive attitude (3.3) on the Likert scale; it was observed that when performing the analysis per strata (Figure 2), the producers of stratum three (large-scale in coffee producing surface) were the ones who presented the best attitude (3.9), followed by the medium-scale (3.7) and finally by the small-scale (2.9). This can be related to the fact that producers from strata two and three present a higher degree of schooling.

The eight reagents for the purpose of analysis are presented in Table 4. They are all addressed in the form of a positive affirmation and are listed next:

A. Soil conservation is necessary for my work in coffee production;

B. Agricultural practices that produce soil erosion should be avoided;

C. The soil and water conservation talks are of great interest; 
Cuadro 4. Posición de cafeticultores en relación con el manejo y conservación del recurso suelo. Table 4. Position of coffee producers with regard to the management and conservation of the soil resource.

\begin{tabular}{|c|c|c|c|c|c|c|c|c|c|}
\hline \multirow{2}{*}{ Reactivo } & \multicolumn{5}{|c|}{ Categorías (\%) } & \multicolumn{4}{|c|}{ Media $\left(\right.$ actitud $\left.^{\dagger}\right)$ por estratos } \\
\hline & TDA & DA & $\mathrm{I}$ & ED & TED & 1 & 2 & 3 & $\mu$ \\
\hline A & 32.5 & 32.5 & 27.5 & 7.5 & - & 3.9 & 3.6 & 4.1 & 3.9 \\
\hline B & 45.0 & 32.5 & 20.0 & 2.5 & - & 4.2 & 4.2 & 4.3 & 4.2 \\
\hline $\mathrm{C}$ & 37.5 & 25.0 & 15.0 & 2.5 & 20.0 & 3.0 & 4.1 & 4.4 & 3.5 \\
\hline $\mathrm{D}$ & 7.5 & 25.0 & 35.0 & 17.5 & 15.0 & 2.5 & 3.4 & 3.9 & 2.9 \\
\hline $\mathrm{E}$ & 40.0 & 37.5 & 22.5 & - & - & 4.1 & 4.2 & 4.4 & 4.2 \\
\hline $\mathrm{F}$ & 50.0 & 37.5 & 12.5 & - & - & 4.3 & 4.4 & 4.4 & 4.4 \\
\hline G & 7.5 & 27.5 & 35.0 & 20.0 & 10.0 & 3.0 & 2.4 & 4.0 & 3.0 \\
\hline$\underline{\mathrm{H}}$ & 20.0 & 32.5 & 10.0 & 30.0 & 7.5 & 3.0 & 3.0 & 4.6 & 3.3 \\
\hline Promedio & & & & & & 3.5 & 3.7 & 4.3 & 3.7 \\
\hline
\end{tabular}

TDA: Totalmente de acuerdo; DA: De acuerdo; I: Indiferente, ED: En desacuerdo y TED: Totalmente en desacuerdo. $\bullet$ TDA: Totally agree; DA: Agree; I: Indifferent, ED: Disagree and TED: Totally disagree.

†Se presentan valores medios basados en la escala de Likert. $\bullet$ Mean values based on the Likert scale are presented.

B. Se debe evitar prácticas agrícolas que produzcan erosión del suelo;

C. Las charlas de conservación de suelos y agua son de gran interés;

D. Estoy dispuesto a realizar análisis de suelo a mi parcela tendientes a su conservación;

E. Estoy dispuesto a realizar obras o prácticas de conservación de suelo en mi parcela;

F. Estoy dispuesto a realizar prácticas de conservación siempre y cuando se me capacite;

G. Estoy dispuesto a conservar el suelo aunque tenga que desembolsar dinero;

H. Estoy dispuesto a emprender labores en beneficio de la conservación del Sitio Ramsar.

De acuerdo con los datos presentados, se puede observar que existió una diversidad de actitudes respecto a los reactivos presentados, obteniendo los tres mayores porcentajes de totalmente de acuerdo en las afirmaciones B, E y F; ésto es, sobre las posiciones de que se deben evitar las prácticas agrícolas que produzcan erosión en los suelos (45.0 \%), y con una actitud altamente positiva en cada uno de los estratos estudiados, $40.0 \%$ sobre estar dispuesto a realizar obras o prácticas de conservación de suelo en la parcela, con una actitud altamente positiva para cada estrato; y finalmente $50.0 \%$ sobre realizar obras o prácticas de conservación de suelos siempre y cuando se les capacite, registrando una actitud de altamente positiva para cada estrato. Es evidente la intención y aceptación de todos los cafetaleros hacia la conservación del suelo. Al respecto, la FAO (1990) indica que el deseo de participación de los agricultores se constituye en
D. I am willing to perform soil analysis in my plot that leads to its conservation;

E. I am willing to carry out soil conservation works or practices in my plot;

F. I am willing to carry out conservation practices as long as I receive training;

G. I am willing to conserve soil even if I have to spend money;

H. I am willing to take up tasks in benefit of conservation of the Ramsar Site.

According to the data presented, it can be observed that there was a diversity of attitudes regarding the reagents presented, obtaining the three highest percentages of total agreement with statements $\mathrm{B}, \mathrm{E}$ and $\mathrm{F}$; that is, about the positions that agricultural practices which produce erosion of the soils must be avoided ( $45.0 \%$ ), and with a highly positive attitude in each one of the strata studied, $40.0 \%$ about being willing to carry out soil conservation works or practices in the plot, with a highly positive attitude for each stratum; and finally, $50.0 \%$ about performing soil conservation works or practices as long as they are trained, recording a highly positive attitude for each stratum. The intention and acceptance of all coffee producers towards soil conservation is evident. In this regard, the FAO (1990) indicates that the farmers' desire to participate is constituted into an essential element of success in any soil conservation program, and which, regardless of how correct the plan is, cannot be applied with a good result without their support and participation. Garry et al. (2007) point out that in any program the most important 
un elemento esencial del éxito en cualquier programa de conservación de suelo, y que independientemente de lo correcto que sea el plan, no puede aplicarse con buen resultado sin el apoyo y la participación de los mismos. Garry et al. (2007) señala que en cualquier programa lo más importante es el interés de los agricultores en cualquier labor de conservación.

Los tres mayores porcentajes de totalmente en desacuerdo se dieron sobre los reactivos C, D y G, esto es; un $20 \%$ está en total desacuerdo sobre que las charlas de conservación de suelos y agua sean de gran interés; sin embargo, a la hora de realizar el análisis por estratos se observa que quienes tienen esa actitud indiferente, en su mayoría, son los pequeños productores (3.0), mientras que los medianos y grandes productores presentan una actitud altamente positiva (4.1) y (4.4) respectivamente. Un $15.0 \%$ también manifestó total desacuerdo sobre estar dispuesto a realizar análisis de suelo en la parcela tendientes a su conservación, encontrando posiciones diversas por estratos: indiferente (2.4) para pequeńos productores, ligeramente positiva (3.4) para medianos y altamente positiva (3.9) para los grandes. Finalmente $10.0 \%$ también manifestó estar en total desacuerdo sobre el hecho de estar dispuesto a conservar el suelo aunque tenga que desembolsar dinero, y precisamente en esta posición fue donde se registraron las menores actitudes en los tres estratos siendo de 3.0, 2.4 y 4.0 para pequeños, medianos y grandes productores respectivamente. $\mathrm{Al}$ respecto, $\mathrm{He}-$ rrera (2004) menciona que el individuo por naturaleza piensa pretender el beneficio ambiental, sin embargo; al momento de invertir algún tipo de recurso para dar las condiciones que propicien este beneficio las intenciones se ven frenadas, aunque en la mayoría de los casos las causas no derivan de la falta de recurso económico sino de falta de visión estratégica. La Figura 3 ilustra lo antes citado.

Es importante mencionar que los productores del estrato 3 "grandes en superficie producida de café" registraron en todos los reactivos actitudes altamente positivas, respecto al proceso de conservación del suelo, a pesar de que esto conlleve a invertir recursos económicos. Lo anterior puede deberse a que de acuerdo con Romero et al. (2005), al realizar un estudio en la Cuenca del río Conchos, concluyeron que los productores con superficies mayores a 10.0 ha presentan una actitud más positiva hacia la adopción de un nuevo sistema de riego. Lo anterior se debe a que tales productores poseen una visión más empresarial y su thing is the interest of farmers in any conservation task.

The three highest percentages of total disagreement happened with reagents C, D and G; that is, $20 \%$ is in total disagreement about the talks on soil and water conservation being of great interest; however, at the time of performing the analysis per strata, it is observed that those who have this indifferent attitude, in their majority, are small-scale producers (3.0), while the medium- and large-scale producers present a highly positive attitude (4.1) and (4.4), respectively. Another $15.0 \%$ also manifested total disagreement about being willing to perform soil analysis in the plot leading to its conservation, and various positions per strata were found: indifferent (2.4) for small-scale producers, slightly positive (3.4) for medium-scale, and highly positive (3.9) for large-scale. Finally, $10.0 \%$ also manifested being in total disagreement about the fact of being willing to conserve soil even when they have to spend money, and precisely in this position it was where the lowest attitudes were found in the three strata: 3.0, 2.4 and 4.0 for small-, medium- and large-scale producers, respectively. In this regard, Herrera (2004) mentions that the individual by nature thinks of seeking environmental benefit; however, at the moment of investing some type of resource to provide the conditions that foster this benefit, their intentions are stopped, although in most of the cases the causes are not derived from the lack of financial resources, but rather from the lack of strategic vision. Figure 3 illustrates this.

It is important to mention that producers from the stratum 3, "large-scale in coffee producing surface", recorded highly positive attitudes in all the reagents, with regard to the process of soil conservation, although this entails investing economic resources. This could be because, according to Romero et al. (2005), when performing a study at the Conchos River Basin, concluded that producers with surfaces larger than 10.0 ha present a more positive attitude towards adopting a new irrigation system. This is because those producers have a more entrepreneurial vision and their income capacity is greater, so there is higher economic capacity to adopt new technology. However, from the parameter of schooling measured in this study, it is also observed that large-scale producers present higher schooling than the rest of the strata.

Another important piece of data to be highlighted, and of great use, is statement $\mathrm{H}$, where small-scale 
- Dispuestos a conservar el suelo aunque tenga que desembolsar dinero

Dispuestos a realizar obras y prácticas de conservación del suelo

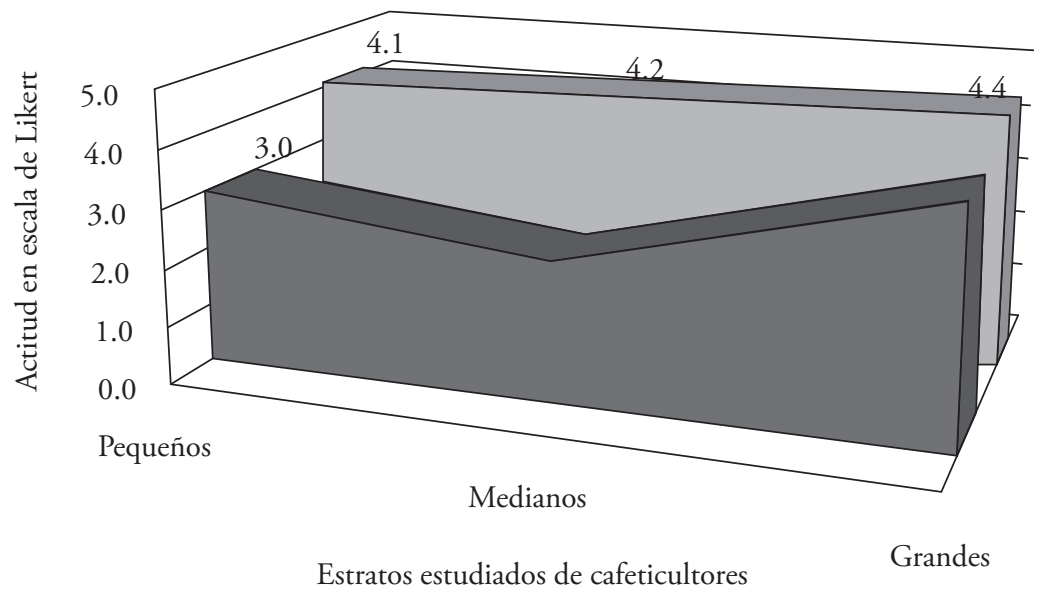

Figura 3. Comparación de la disposición respecto al condicionamiento de recurso.

Figura 3. Comparison of willingness regarding conditioning of the resource.

capacidad de ingresos es mayor, por lo que hay más capacidad económica para adoptar nueva tecnología. Sin embargo, por el parámetro de escolaridad medido en este estudio, se observa además que los grandes productores presentan una escolaridad mayor al resto de los estratos.

Otro dato importante y de gran utilidad a destacar es sobre la afirmación $\mathrm{H}$, donde los pequeños y medianos productores mostraron indiferencia (3.0) con relación a estar dispuesto a emprender labores en beneficio de la conservación del Sitio Ramsar. Al respecto se encontró que los cafetaleros de las comunidades del municipio de Teocelo presentan una actitud altamente positiva (4.1) contra una actitud indiferente (2.3) sobre los de Xico. Lo anterior puede deberse a que en Teocelo, las autoridades municipales de los últimos años se han ocupado de dar difusión entre los habitantes sobre la importancia de conservar al Sitio Ramsar. Lo mencionado concuerda con lo expuesto por Brejda et al. (2000) y Cotler et al. (2007) quienes indican que la conservación de suelos debe ser un asunto de interés público impulsado por sus gobernantes a nivel región y para que esto tenga efecto, los principales actores involucrados deben ser sus habitantes.

\section{Conclusiones}

Este es un trabajo pionero que evalúa, en uno de los Sitios Ramsar más importante de México, la actitud de los cafetaleros respecto al manejo y conservación del suelo. Se encontró una tendencia hacia la reducción de las prácticas y obras de conservación del suelo en el tiempo a partir de 1989. Esto debido a la and medium-scale producers showed indifference (3.0) with regard to being willing to undertake work in benefit of conservation of the Ramsar Site. In this regard, it was found that the coffee producers in communities of the Teocelo municipality present a highly positive attitude (4.1) versus an indifferent attitude (2.3) from those in Xico. This could be because in Teocelo, the municipal authorities of recent years have been busy divulging among residents the importance of conserving the Ramsar Site. This agrees with what was exposed by Brejda et al. (2000) and Cotler et al. (2007), who indicate that soil conservation must be an issue of public interest driven by government leaders at the regional level, and for this to have an effect, the main actors involved must be the residents.

\section{Conclusions}

This is a pioneering study that evaluates, in one of the most important Ramsar Sites in México, the attitude of coffee producers regarding soil management and conservation. A tendency towards reduction of the practices and works for soil conservation was found in the time since 1989. This is due to the disappearance of the influence by INMECAFÉ, regarding the technical recommendation and economic support for the implementation of works and practices for soil management and conservation. However, with the coffee crisis, the need to reduce inputs and increase practices at the plot level has arisen, achieving, occasionally and forcibly, environmental benefits for the coffee production agroecosystem. 
desaparición de la influencia que tuvo el INMECAFÉ, respecto a la recomendación técnica y apoyo económico sobre la implementación de obras y prácticas de manejo y conservación del suelo. Sin embargo, con la crisis cafetalera, se ha dado la necesidad de reducir insumos e incrementar prácticas a nivel parcelario que han logrado eventual y forzadamente beneficios ambientales para el agroecosistema cafetalero.

Los cafeticultores mostraron una actitud ligeramente positiva (3.3) hacia conservar el medio ambiente y sus recursos en beneficio del Sitio Ramsar.

La actitud respecto al manejo y conservación del recurso suelo mediante la implementación de obras o prácticas fue altamente positiva para toda la población, sin embargo; al expresar la condicionante de si estarían dispuestos a conservar el suelo aunque implique desembolso económico, la actitud positiva fue disminuyendo y muestra una relación directa con respecto al número de hectáreas que posee cada productor, ya que productores con mayor superficie cultivada tuvieron una mayor actitud positiva hacia afirmación.

\section{Agradecimientos}

Al Consejo Nacional de Ciencia y Tecnología (CONACYT), por el apoyo otorgado dentro de la Convocatoria Estancias Posdoctorales Vinculadas al Fortalecimiento de la Calidad del Posgrado Nacional 2013 (3), que permitieron éste proyecto. Al Colegio de Veracruz por el apoyo otorgado para las facilidades de ésta investigación.

\section{Literatura Citada}

Altamirano, M., G. Galloway, B. Louman, K. Prins, y L. Ortega. 2004. Actitudes, conocimientos, manejo de fincas y percepción de los campesinos hacia el uso del recurso bosque en comunidades aledañas a la Reserva Biológica Indio Maíz, El Castillo, Río San Juan, Nicaragua. Rev. Recursos Naturales y Ambiente 43: 49-61.

AMECAFÉ (Asociación Mexicana de la Cadena Productiva del Café). 2012. Plan Integral de Promoción del Café de México 2012. 63 p.

Arriaga, L., V. Aguilar, y J. Alcocer. 2002. Aguas continentales y diversidad biológica de México. Comisión Nacional para el Conocimiento y Uso de la Biodiversidad. México. CONABIO.

Betancourt-Yánez, Pedro, y Pilar Pulido. 2006. Actitud de los agricultores hacia el manejo y conservación del suelo y agua en dos comunidades rurales del Estado Lara, Venezuela.

Biarnes O. A., y T. Duchenne. 1987. El corte del café en los municipios de Coatepec, Xico, Teocelo y Cosoutlán. Estado de Veracruz. Documento de trabajo. Consultado en: http://
Coffee producers showed a slightly positive attitude (3.3) towards conserving the environment and its resources in benefit of the Ramsar Site.

The attitude regarding the management and conservation of the soil resource through implementation of works and practices was highly positive for the whole population; however, when expressing the determinant of whether they would be willing to conserve the soil even if it implies financial disbursement, the positive attitude increasingly decreased and showed a direct relation to the number of hectares that each producer owns, since producers with a greater surface cultivated had a higher positive attitude towards affirmation.

\section{ACKNOWLEDGMENTS}

To the National Science and Technology Council (Consejo Nacional de Ciencia y Tecnología, CONACYT), for the support granted within the Convocatoria Estancias Posdoctorales Vinculadas al Fortalecimiento de la Calidad del Posgrado Nacional 2013 (3), which allowed this project. To Colegio de Varacruz for the support granted to ease this research.

- End of the English version -

horizon.documentation.ird.fr/exl-doc/pleins_textes/doc3405/27005.pdf 45 p.

Brejda J., Moorman, T., Douglas L. Karlen, and H.A. Thanh. 2000. Identification of Regional Soil Quality Factors and Indicators I. Central and Southern High Plains. In: Soil Science Society of America Journal. Vol. 64 No. 6. p: 2115-2124.

Cotler, Helena, Esthela Sotelo, Judith Domínguez, María Zorrilla, Sofía Cortina, y Leticia Quiñones. 2007. La conservación de suelos: un asunto de interés público.Gaceta Ecológica, abril-junio, 5-71.

Ejea Mendoza, María Teresa. 2009. Café y cultura productiva en una región de Veracruz. Nueva antropología, 22(70), 33-56.

FAO. 1990. Conservación de suelos para los pequeños agricultores en las zonas tropicales húmedas. Boletín de Suelos de la FAO. $\mathrm{N}^{\circ}$ 60. Roma. $122 \mathrm{p}$.

FAO-WOCAT. 2012. La Reseńa Mundial de Enfoques y Tecnologías de la Conservación. Disponible en: http://www.fao.org/ soils-portal/manejo-del-suelo/conservacion-del-suelo/es/

Flores, N. 2011. Estrategias de sensibilización a habitantes y usufructuarios del Sitio Ramsar Cascadas de Texolo y su entono, municipio de Xico, Ver. Tesis de Licenciatura. Facultad de Biología Xalapa. Universidad Veracruzana. 99 p.

Foley, J. A., R. DeFries, G. Asner, C. Barford, G. Bonan, S. Carpenter, S. Chapin, M. Coe, G. Daily, H. Gibbs, J. Helkowski, T. Holloway, E. Howard, C. Kucharik, C. Monfreda, J. Patz, C. Prentice, N. Ramankutty, and P. Zinder. 2005. Glo- 
bal consequences of land use. Science, no. 309. pp: 570-574.

Folgueiras, P. 2007. La evaluación participativa de un programa de formación para una participación intercultural. Revista de Investigación Educativa 25 (2).491-511.

Garry L. Schaefer, Michael H. Cosh, and Thomas J. Jackson. 2007. The USDA Natural Resources Conservation Service Soil Climate Analysis Network (SCAN). J. Atmos. Oceanic Technol., 24, 2073-2077.

Hartley, James. 2014. Some thoughts on Likert-type scales. International Journal of Clinical and Health Psychology. 8386.

Hernández, S. M. 2014. Estado actual de la Cafeticultura en el Sitio Ramsar Cascadas de Texolo y su entorno. Tesis de Maestría en Desarrollo Regional Sustentable del Colegio de Veracruz (El Colver). 130 p.

Herrera, L. 2004. Investigación científica: inversión para conservar. Interciencia, 29(9).

Hoffman. O. 1986. Movimientos geográficos y economía cafetalera en el centro del Estado de Veracruz. (Xalapa-Coatepec). Cuadernos del IIESE. N. 13. pp: 57-84.

Likert, R. 1932. A technique for the measurement of attitudes. Archives of Psychology 140: 1-55.

Nava-Tablada, M. E. 2012. Migración Internacional y Cafeticultura en Veracruz, México. Migraciones internacionales, vol. 6, núm. 3.

Noriega Altamirano, Gerardo; Brenda Cárcamo Rico, Manuel Ángel Gómez Cruz, Rita Schwentesius Rindermann, Sergio Cruz Hernández, Jesús Leyva Baeza, Eduardo García de la Rosa, Ulises Iván López Reyes, y Alexander Martínez Hernández. 2014. Intensificación de la producción en la agricultura orgánica: caso café. Revista Mexicana de Ciencias Agrícolas, Enero-Febrero, 163-169.
Pérez, A. P. 2009. Los espacios de producción de café sustentable en México en los inicios del siglo XXI. Revista Pueblos y Fronteras Digital, Junio-Noviembre, 116-156.

Pérez, O., O. Ramírez, L. Hilje, y J. Karremans. 1997. Potencial de adopción de dos opciones tecnológicas de manejo integrado de plagas (MIP) aplicando tres técnicas de extensión con productores de tomate en el Valle Central Occidental, Costa Rica. Manejo Integrado de Plagas 43:19-30.

Rojo, R. 2011. Análisis de la situación actual del Sitio Ramsar Cascadas de Texolo y su entorno, Municipio de Xico, Ver. Tesis de Licenciatura. Facultad de Biología. Xalapa. Universidad Veracruzana. $104 \mathrm{p}$

Romero P., R., J. Monnier, y R. Miquel. 2005. Organización social y conflictos por el agua en los distritos de riego de la cuenca del Río Conchos. In: Vargas, S. y Mollard, E. Problemas socioambientales y experiencias organizativas en las cuencas de México. IMTA-IRDCONACYT, México. pp: 76.

Salas, J. 2002. Actitud del productor agrícola de comunidades del Valle de Quíbor, Venezuela, hacia el manejo integrado de plagas en tomate. Desarrollo Rural 4-5: 183-213

Sandín, M. P. 2003. Investigación Cualitativa en Educación. Fundamentos y Tradiciones. Madrid: Mc Graw-Hill.

Secretaría de la Convención de Ramsar. 2007. Designación de sitios Ramsar: Marco estratégico y lineamientos para el desarrollo futuro de la Lista de Humedales de Importancia Internacional. Manuales Ramsar para el uso racional de los humedales, 3a edición, vol. 14. Secretaría de la Convención de Ramsar, Gland (Suiza). 122 p.

Torres, N. C. 2005. Ficha Informativa de los Humedales de Ramsar (fir). Sitio Ramsar Cascada de Texolo y su entorno. COEPA, Gobierno del Estado de Veracruz. En Coordinación con la oficina de la Convención de Ramsar. Gland, Suiza. Xalapa, Veracruz, México. 